\title{
Making FDI More Sustainable: Towards an Indicative List of FDI Sustainability Characteristics
}

\author{
Karl P. Sauvant \\ Columbia University, Columbia Center on Sustainable Investment, New \\ York, United States \\ karlsauvant@gmail.com \\ Howard Mann \\ International Institute for Sustainable Development, Winnipeg, Canada \\ howardlmann@gmail.com
}

\begin{abstract}
Reaching the Sustainable Development Goals has become the lodestar of development policymaking. Increased sustainable Foreign Direct Investment (FDI) flows to developing countries can contribute to reaching the Goals. This article analyzes 150 instruments (treaties, standards, codes) prepared by key stakeholder groups in the FDI space bearing on the relationship between host countries and foreign investors, to identify FDI sustainability characteristics along the following four dimensions: economic, social and environmental development and governance. These instruments indicate especially the contributions government expect multinational enterprises (MNEs) to make to host countries and those MNEs expect to make to host countries. The analysis yields a set of indicative 'common FDI sustainability characteristics', and 'emerging common FDI sustainability characteristics'. These characteristics can guide various stakeholder groups that seek to increase the contribution of FDI to development; the
\end{abstract}

* Karl P Sauvant is Resident Senior Fellow, Columbia Center on Sustainable Investment, a joint center of Columbia Law School and the Earth Institute, Columbia University. Howard Mann is Senior International Law Advisor at the International Institute for Sustainable Development. This article is a revised version of part of a paper by Karl P Sauvant and Howard Mann, 'Towards an Indicative List of FDI Sustainability Characteristics' (2017) Geneva: ICTSD and WEF. The authors are grateful to Ana Arias Urones, Nathalie Bernasconi, Xavier Carim, Emma De Koster, Felipe Hees, Ting-Hsuan Kuo, Ana Novik, Caroline Rees, Githa Roleans, Lou Wells, and three anonymous peer reviewers for their very helpful comments, and to Nandini Ravichandran and Thor Petersen for their excellent research assistance and drafting support. 
World Trade Organization's Structured Discussions concerning an investment facilitation framework for development; and to arbitrators seeking to take the development dimension into account when deliberating investor-state disputes.

\section{Keywords}

business and human rights - foreign direct investment - multinational enterprises sustainable development goals (SDGs) - sustainability characteristics - sustainability sustainable development

\section{$1 \quad$ Introduction}

Reaching the Sustainable Development Goals (SDGs) is the principal economic development challenge of our time - it has become the lodestar of development policymaking, supported by all countries. Increased foreign direct investment (FDI) can make a contribution to reaching the SDGs. However, the issue is not only more FDI, but even more so investment that makes a maximum contribution to the sustainable development of host countries, that is, investment that has the characteristics of 'sustainable FDI'. Identifying 'FDI sustainability characteristics' is the primary purpose of this article.

This, in turn, has practical implications, because, in the end, it is the individual investment project that has a direct impact on a host country's development. Therefore, knowing what aspects of FDI are particularly relevant to advance development is important for various stakeholders that seek to increase the contribution that such investment can make to sustainable development, including especially governments and their investment promotion agencies (IPAs), as well as multinational enterprises (MNEs) interested in the impact they have on host countries. Moreover, the Structured Discussions on a multilateral framework on investment facilitation for development currently underway in the World Trade Organization (WTO) would benefit from a reference list of FDI sustainability characteristics in order to be able to focus on what type of investment should benefit particularly from any facilitation mechanisms. ${ }^{1}$ Finally, since the issue of FDI quality, in terms of the contribution that FDI can make to development, is also beginning to be considered in

1 International Centre for Trade and Sustainable Development (ICTSD), 'Crafting a Framework on Investment Facilitation' (Geneva 2018) available at <https://ictsd.org/sites/ default/files/research/crafting_a_framework_on_investment_facilitation-ictsd-policy_brief .pdf> accessed 4 June, 2018. 
arbitral proceedings, an indicative list of sustainability characteristics can give guidance to the deliberations of arbitral tribunals. ${ }^{2}$

While the issue of the quality of FDI is not new (Section 2), the question of what kind of FDI can be considered as making a maximum contribution to development can be answered best by examining what principal stakeholders themselves expect FDI to contribute to sustainable development, as identified in instruments formulated by them about the relationship between host country governments and foreign investors (Section 3 ). The analysis of these instruments - the most important part of this article - leads to the identification of FDI sustainability characteristics, that is, those attributes of FDI projects that are expected to contribute to sustainable development (Section 4). The conclusions (Section 5) draw attention to the need to promote and use the sustainability characteristics in future law and policymaking.

The amount of investment needed to meet the challenges of the future is tremendous: meeting the SDGs alone requires trillions of investment dollars. At the same time, the annual financing gap to reach the SDGs for the developing countries alone has been estimated at USD 2.5 trillion. ${ }^{3}$ FDI can make a contribution to meeting these investment needs. To make a substantial difference, however, FDI flows would have to increase significantly from the USD 1.2 trillion that they were in 2018. ${ }^{4}$

However, the issue is not only more FDI, but it also needs to be the right kind of FDI: what is referred to as 'sustainable FDI' in this article.

This concerns the quality of FDI - not a new issue. ${ }^{5}$ On balance, most FDI can contribute to sustainable development, at least if the conditions

2 Examples include Salini Costruttori SpA v Kingdom of Morocco, ICSID Case No ARB/oo/4, Decision on Jurisdiction (31 July 2001) para 57; Biwater Gauff (Tanzania) Ltd. $v$ United Republic of Tanzania, ICSID Case No ARB/05/22, Award (24 July 2008) para 320, Inmaris Perestroika Sailing Maritime Services GmbH and Others v Ukraine, ICSID Case No ARB/o8/8, Decision on Jurisdiction (8 March 2010) para 132, and Alpha Projektholding GmbHv Ukraine, ICSID Case No ARB/07/16, Award (8 November 2010) para 330. These decisions include references to contribution to infrastructure, technology transfer, local employee training, and the generation of government revenue as characteristics associated with the notion of an investment contribution to development.

3 United Nations Conference on Trade and Development (UNCTAD), World Investment Report 2014: Investing in the SDGs: An Action Plan (United Nations 2014) xi.

4 UNCTAD, Global Investment Trend Monitor, issue 31 (January 2019) 1.

5 See in this context also the Organisation for Economic Co-operation and Development (OECD) Secretariat's 'FDI qualities project', a project that seeks to provide governments 
surrounding an investment encourage such a result. Nonetheless, a number of countries distinguish between different kinds of inward FDI on the basis of various considerations. For example, some governments submit certain types of inward FDI - typically mergers and acquisitions, but also greenfield projects (sometimes over certain size thresholds) - to various tests, such as net-benefit tests or national security tests. ${ }^{6}$ Canada, for example, uses the former test, ${ }^{7}$ while the United States is a prominent example for using the latter. ${ }^{8}$ Many governments limit (or entirely restrict) inward FDI in certain services, manufacturing industries, natural resources, and infrastructure. Many developed and developing countries have adopted this approach for a variety of reasons, including to encourage the development of domestic firms in these industries, for strategic security reasons or to protect certain cultural industries, public services or small and medium-sized firms.

Moreover, most governments apply specific criteria to proposed large-scale or ecologically sensitive investments, in the form of environmental and social impact assessments, now also increasingly including human rights assessments. Further, maximizing the positive economic and social benefits for a community is now a standard metric in many natural resource sectors, epitomized, for example, by the notion of 'shared value' in the mining sector.9

Finally, many governments consider that some types of investment, especially when supported by national and international policies, can make a particular contribution to the development of their economies. This is reflected in the fact that more and more IPAs in developed and developing

with a tool kit to attract investment that contributes as much as possible to sustainable development. For that purpose, the project has identified five clusters of 'FDI qualities indicators': productivity-innovation, skills, job quality, gender, and carbon footprint. See OECD, FDI Qualities Toolkit: Investment for Sustainable Growth: Progress Report II (October 2018); OECD, FDI Qualities Toolkit: Investment for Inclusive and Sustainable Growth. Progress Report III (March 2019). For a comparative discussion of the approach taken by the OECD Secretariat and the authors of this article, see Karl P Sauvant, 'Determining Quality FDI: A Commentary on the OECD's “FDI Qualities Project"' (Kluwer Arbitration Blog, 20 April 2019) <https://ssrn. com/abstract $=3376328>$ accessed 18 October 2019 .

6 Namibia Investment Promotion Act (signed 12 August 2016) act no 9, part 3, Government Gazette of the Republic of Namibia, no 6110 (31 August 2016).

7 Investment Canada Act, RSC 1985, c 28 (1st Supp) para 20 <http://laws-lois.justice.gc.ca/eng/ acts/I-21.8/index.html $>$ accessed 13 April 2018.

8 In the United States, the Committee on Foreign Investment in the United States (CFIUS) screens mergers and acquisitions that would result in the foreign control of US firms considered important in light of national security concerns. See, US Department of the Treasury, 'The Committee on Foreign Investment in the United States (CFIUS)' (20 December 2012) <https://treasury.gov/resource-center/international/Pages/Committee-on-Foreign -Investment-in-US.aspx > accessed 13 April 2018.

9 Michael E Porter and Mark R Kramer, 'Creating Shared Value' (2011) 89 Harv Bus Rev 62. 
countries alike focus on attracting certain types of projects, as well as FDI in specific industries they consider as contributing most to their own development priorities. Thus, the United Kingdom determines the value of an FDI project (and hence its eligibility for government support) by examining a number of quantitative and qualitative indicators. Quantitative indicators (such as the total value of an investment, number of new jobs created) relate mostly to larger projects that are expected to deliver higher economic and social benefits and have other multiplier benefits. The government also reviews qualitative indicators, namely the salary level of new jobs created or a project's researchand-development focus, whether or not an investment is a global or regional headquarters, the quality of the investor, and the export potential. ${ }^{10}$ The Republic of Korea's IPA mentions the enhancement of domestic economic competitiveness as a very desirable attribute. ${ }^{11}$ Nigeria provides incentives for, inter alia, telecommunications, electricity and transport industries. ${ }^{12}$ The Chilean IPA targets the food, infrastructure and tourism industries. ${ }^{13}$ Hungary's IPA provides targeted services for, among others, the automotive and electronics industries and shared service centers. ${ }^{14}$ Vietnam, meanwhile, provides incentives for investments in new technologies, agriculture and forestry, and environmentally friendly technology. ${ }^{15}$

Countries that pursue a targeted investment approach may not hold that there is 'desirable' and 'non-desirable' FDI within the sectors that are open to FDI. However, they consider that investment with certain characteristics is particularly desirable and, therefore, might qualify for various investment incentives. In this sense, the approach is not different from the one taken by some countries towards encouraging renewable energies or providing valueadded tax exemptions in the mining sector to encourage socially desirable but privately insufficiently profitable investment.

\footnotetext{
10 Interview with a staff of the Department for International Trade about the DIT Investment Playbook, an internal non-published document setting out the operating principles for delivering FDI into the United Kingdom.

11 InvestKorea, 'Foreign Investment Promotion Policy: Overview' <http://investkorea.org/ en/policy/overview.do > accessed 13 April 2018.

12 Nigeria Investment Promotion Commission <https://invest-nigeria.com/investment -incentives/> accessed 13 April 2018.

13 Invest Chile, 'Key Sectors' <https://investchile.gob.cl/> accessed 13 April 2018.

14 Hungarian Investment Promotion Agency, 'Key Investment Sectors' <https://hipa.hu/ main> accessed 13 April 2018.

15 Vietnam Trade Promotion Agency <http://en.vietrade.gov.vn/> accessed 13 April 2018.
} 
As far as the 17 SDGs and their 169 targets are concerned, it cannot be expected that FDI contributes to all of them. ${ }^{16}$ Achieving most of the Goals is primarily the responsibility of governments. Arguably, one of the most important Goals is Goal 8, 'Promote sustained, inclusive and sustainable economic growth, full and productive employment and decent work for all', as economic growth and employment provide the basis for reaching many of the other Goals. FDI can certainly make a contribution to this Goal, and can in that way potentially make the most important contribution to reach the SDGs. Beyond that, the role of FDI is specifically mentioned in connection with a number of other goals and targets, such as Goal 10, 'Reduce inequality within and among countries' (with its specific target 10.b 'Encourage official development assistance and financial flows, including foreign direct investment, to States where the need is greatest'), and Goal ${ }_{17}$, 'Strengthen the means of implementation and revitalize the Global Partnership for Sustainable Development' (with its specific target 17.3 'Mobilize additional financial resources for developing countries from multiple sources' and its specific indicator 17.3.1 'Foreign direct investment (FDI) ... as a proportion of total domestic budget'). FDI can also play an important role in such areas as building infrastructure (Goal 9, including energy infrastructure (indicator 7.b.1)), creating effective, accountable and inclusive institutions (Goal 16), developing, transferring, disseminating, and diffusing technology (target 17.7), and increasing exports (target 17.11). To mobilize finance, target 17.5 is in fact: 'Adopt and implement investment promotion regimes for least developed countries'.

As this discussion about the quality of FDI indicates, some types of investment can make - in the eyes of governments (and for governments, FDI is merely a tool to advance their development) - more of a contribution to a host country's development than other types, with the most desirable contributions sought depending on a host country's development strategy. In the context of reaching the SDGs, the challenge then becomes to identify what according to principal stakeholders - 'sustainable FDI' is, which is the topic of the next two sections.

16 Inter-Agency and Expert Group on SDG Indicators, 'Revised List of Global Sustainable Development Goal Indicators' (2017) E/CN.3/2017/2, Annex III <https://unstats.un.org/ sdgs/indicators/official\%2orevised\%2olist\%20of\%2oglobal\%20sdg\%2oindicators.pdf> accessed 13 April 2018. 
A rough definition of 'sustainable FDI' is: commercially viable investment that makes a maximum contribution to the economic, social and environmental development of host countries and takes place in the framework of fair governance mechanisms. ${ }^{17}$ This is a definition that goes beyond 'do no harm' and calls for active efforts on the part of MNEs and their foreign affiliates to contribute as much as possible to the sustainable development of their host countries. In other words: sustainable FDI for sustainable development.

It should be noted that the definition deliberately speaks about 'commercially viable investment', recognizing that making a maximum contribution may involve costs for the firms involved and that, if these costs are higher than the profits that can be expected from a given project, the investment normally will not be undertaken. This also holds true from the host country's perspective: if the costs created by a project for a host country are higher than the expected benefits, it will normally not make sense for a host country to allow the investment; this may become particularly relevant in the case of large projects with considerable impact (such as in extractive industries). The challenge therefore becomes to find the right point at which making an investment still makes sense for foreign investors while making a substantial contribution to host countries - which is a question that, in practice, most likely arises only in the case of large projects. Similar considerations also apply to the issues of 'do no harm' and 'active efforts'. An example of the former concerns various substantial negative environmental effects that need to be avoided or mitigated. An example of the latter concerns the creation of linkages between foreign affiliates and domestic firms. Since linkages can be important conduits for disseminating the tangible and intangible benefits of foreign affiliates to

17 Karl P Sauvant, 'We Need an International Support Programme for Sustainable Investment Facilitation' (6 July 2015) 151 Columbia FDI Perspectives <https://papers.ssrn.com/sol3/ papers.cfm?abstract_id=2896212> accessed 18 October 2019; Karl P Sauvant and Khalil Hamdani, 'An International Support Programme for Sustainable Investment Facilitation' (International Centre for Trade and Sustainable Development, July 2015) <https://papers .ssrn.com/sol3/papers.cfm?abstract_id=3143372 $>$ accessed 18 October 2019. The concrete elements of these four dimensions - each of which is linked to various SDGs - are discussed below. A broader example of a fair governance mechanism concerns investment contracts, often concluded for large-scale extractive industry, agricultural land and infrastructure projects. Typically, in these situations, host countries do not have the human or financial resources to negotiate in a manner that ensures that these contracts are as good for them as they could be. Considering that such contracts determine the distribution of benefits between host countries and foreign investors for years (if not decades) to come, they are invariably of key importance for advancing national development and, therefore, constitute an important governance mechanism. 
domestic firms (and, therefore, help to upgrade the latter), they are typically in the interest of host countries. At the same time, they may well be in the interest of foreign investors as well, at least if linkages allow local sourcing at competitive costs and quality, and if there may be the potential threat of supply-chain disruptions. Creating linkages may require overcoming inertia on the part of MNEs, as well as governments assisting domestic firms in becoming 'linkage ready'. In particular, in the case of large projects with significant impacts, making a substantial contribution to the sustainable development of host countries may bear directly on MNEs' social license to operate.

Finally, there is the question whether using FDI sustainability characteristics leads to discrimination between MNEs and domestic firms. This is of course an important policy question involving a number of considerations. ${ }^{18}$ Suffice it to say that the approach taken here is the same as that taken by the 2017 updated International Labour Organization (ILO) Tripartite Declaration of Principles Concerning Multinational Enterprises and Social Policies. As in the case of that Declaration, the intention here is not to introduce a distinction between multinational and domestic enterprises: '5. These principles do not aim at introducing or maintaining inequalities of treatment between multinational and national enterprises. They reflect good practice for all. Multinational and national enterprises, wherever the principles of the MNE Declaration are relevant to both, should be subject to the same expectations in respect of their conduct in general and their social practices in particular.'19

What, then, could be the methodology to determine FDI sustainability characteristics and an indicative list of such characteristics? The approach taken here is to establish such a list on the basis of what the principal stakeholders in the relationship between host countries and international investors themselves identify as those characteristics. More specifically, among stakeholders, it is governments that should know best how, given all relevant variables and constraints, FDI can contribute best to sustainable development; similarly, the private sector should know best what it can contribute towards this objective.

18 One of these considerations is that foreign investors typically benefit from the protection of international investment agreements and, in particular, have access to the agreements' investor-state dispute-settlement mechanism, a mechanism that can only be evoked by foreign investors and to which domestic firms do not have access.

19 International Labour Organization (ILO), Tripartite Declaration of Principles Concerning Multinational Enterprises and Social Policy (5th edn, ILO March 2017) $3<$ http://ilo .org/wcmsp5/groups/public/---ed_emp/---emp_ent/---multi/documents/publication/ wcms_094386.pdf> accessed 13 April 2018. Hence, an indicative list of FDI sustainability characteristics would also be of use to governments seeking to encourage sustainable domestic investment. 
The principal stakeholders are:

- Negotiators of international investment agreements who, on behalf of their governments, seek to negotiate treaties that not only protect international investors but also advance the sustainable development of their countries and, hence, can benefit from a list of broadly accepted sustainability characteristics. This is particularly important now, because Structured Discussions in the WTO consider whether to seek an investment facilitation framework and, hence, the question arises what kind of FDI might deserve special attention. ${ }^{20}$

- Host country governments and IPAs seeking to attract sustainable FDI.

- Home country governments supporting their firms to invest abroad through various home country measures that are (or can be) linked to certain conditions (such as the impact of FDI projects on the environment in host countries).

- Intergovernmental organizations seeking to develop their own guidelines to further the sustainable development impact of FDI.

- Global business associations seeking to provide guidance to their members regarding sustainable FDI for sustainable development.

- Private institutional investors, often controlling substantial pools of funds, seeking to provide guidance to their clients regarding sustainable FDI.

- Industry associations seeking to do the same.

- International investors seeking to maximize the benefit of their investments not only for themselves, but also for the sustainable development of their host countries.

- Civil society organizations or communities seeking to monitor particular FDI projects or responsible business conduct in more general terms.

Arbitrators in international investment disputes wanting to take the development impact of investment projects into account could also benefit from a list of FDI sustainability characteristics.

The expectations of these stakeholders are reflected in various treaties, standards and codes (collectively called 'instruments' in the following discussion) bearing on the relationship between host country governments and foreign investors. These instruments indicate: (i) the kind of contributions governments and intergovernmental organizations expect MNEs to make to host countries; (ii) what kind of contributions MNEs and business organizations expect to make to host countries; and (iii) what others expect from MNEs in this respect. 
More specifically, for the purpose of this article, 150 instruments prepared by the stakeholders listed above were examined to determine what contributions to host country development they specify and/or what needs to be done to mitigate or avoid possible negative impacts of investments. ${ }^{21}$ Furthermore, for each category of instruments, illustrative examples are provided of contributions that could be included in an indicative list of FDI sustainability characteristics. In determining the instruments, emphasis was given to the most recent instruments. These instruments are:

- International investment agreements (IIAs - treaties between and among governments dealing with international investment matters, most prominent among them bilateral investment treaties (BITs). ${ }^{22}$ The BIT between Brazil and Malawi, the Comprehensive Economic and Trade Agreement between Canada and the European Union (CETA), the Lomé Convention between the members of the African, Caribbean and Pacific Group and the European Union (ACP-EU Partnership Agreement), the Southern African Development Community Model BIT, and the Draft Pan-African Investment Code mention the strengthening of local capacities through close cooperation with the local community and encouraging

21 The list of instruments to consider in this context is vast. For example, there are over 3,000 international investment agreements and considerably more than 100,000 MNEs (many of which have corporate social responsibility statements), and many host countries have laws/regulations and/or other instruments that bear on international investors and their contributions to national economies. To keep the list of instruments to be examined manageable, the focus was on recent and important instruments, and at times a judgment needed to be made to determine which instruments were most appropriate for the analysis. (See also further explanations below.) It cannot be said, therefore, that the 150 instruments examined are representative of the universe of such instruments. (For a listing of these instruments and a more detailed description of the methodology used, see Karl P Sauvant and Howard Mann, 'Towards an Indicative List of FDI Sustainability Characteristics' (2017) ICTD and World Economic Forum, annexes II and III <https:// papers.ssrn.com/sol3/papers.cfm?abstract_id=3055961 $>$ accessed 18 October 2019. Hence, the lists of common and emerging common sustainability characteristics is described as 'indicative' in the text. Of the 150 instruments, 101 are linked to governments, 47 to the private sector and 2 to NGOs.

22 There are over 3,000 such agreements. For the analysis for this article, 44 treaties were examined, including all full-text English-language treaties between February 2015 and June 2017 that were available (as of June 2017) on the UNCTAD website (Investment Policy Hub). For the purpose of this analysis, no distinction was made as to whether a characteristic is contained in the preamble of a treaty or the text itself. However, a distinction was made between the general recognition of a characteristic, for example, the need to protect the environment, and more specific expressions of a characteristic, for example, the need to reduce greenhouse gas emissions. 
the development of local human capital; ${ }^{23}$ the protection of labour rights, including the prohibition of forced and child labour; ${ }^{24}$ respect for human rights; ${ }^{25}$ and technology transfer. ${ }^{26}$ Further, article 14 of the Investment Promotion and Protection Agreement between Morocco and Nigeria mandates environment and social impact assessment screening and the application of precautionary principles as ways to mitigate negative impacts.

- Non-binding intergovernmental instruments. ${ }^{27}$ The United Nations Guiding Principles on Business and Human Rights (endorsed by the United Nations Human Rights Council), the ILO Tripartite Declaration of Principles Concerning Multinational Enterprises and Social Policy (negotiated and adopted by governments of home and host countries of MNEs, as well as global representative bodies of employers and workers), the Organisation for Economic Co-operation and Development (OECD) Guidelines for Multinational Enterprises ${ }^{28}$ (developed primarily by MNE home country governments to guide the behaviour of their companies

23 Investment Cooperation and Facilitation Agreement Between the Federative Republic of Brazil and the Republic of Malawi (signed 25 June 2015) (Brazil-Malawi BIT) art 9(2) (c)-(d) <http://investmentpolicyhub.unctad.org/Download/TreatyFile/4715> accessed 13 April 2018.

24 Comprehensive Economic and Trade Agreement Between Canada, of the One Part, and the European Union and Its Member States, of the Other Part (2017) OJ L11/23 (CETA) art 23.3 <http://data.consilium.europa.eu/doc/document/ST-10973-2016-INIT/en/pdf> accessed 13 April 2018.

25 ACP-EU Partnership Agreement (Partnership Agreement Between the Members of the African, Caribbean and Pacific Group of States of the One Part, and the European Community and Its Member States, of the Other Part) (signed 23 June 2005, revised 25 June 2005 and 22 June 2010) art 9 <http://ec.europa.eu/development/body/cotonou/ pdf/agro1_en.pdf\#zoom=100> accessed 13 April 2018; Southern African Development Community (SADC) Model Bilateral Investment Treaty Template with Commentary (July 2012) art 15.1 <http://www.iisd.org/itn/wp-content/uploads/2012/10/sadc-model-bit -template-final.pdf > accessed 13 April 2018.

26 Draft Pan-African Investment Code (distributed 26 March 2016) art $17<$ http://repository .uneca.org/bitstream/handle/10855/23009/b11560526.pdf?sequence=1> accessed 13 April 2018.

27 The principal instruments in this area are mentioned in the text. However, for the analysis for this article, 15 such instruments were examined.

28 Michael Gestrin and Ana Novik, 'Identifying and Measuring the Sustainability Characteristics of FDI', OECD: Global Forum on International Investment (2017) $<$ http://oecd.org/investment/globalforum/2017-GFII-Background-Note-Identifying-and -measuring-the-sustainability-characteristics-of-FDI.pdf> accessed 18 October 2019. It should be noted that the Guidelines (while voluntary) are backed up by the Investment Declaration and an OECD's Council Decision that creates legal obligation to create National Contact Points. 
in host countries), ${ }^{29}$ and the United Nations Conference on Trade and Development (UNCTAD) Investment Policy Framework for Sustainable Development (developed by the UNCTAD Secretariat) mention avoidance of human rights infringements; ${ }^{30}$ assurance of worker safety; ${ }^{31}$ diffusion of technology; ${ }^{32}$ and the building of local capacity. ${ }^{33}$ In addition to recommending a risk-based due diligence for MNEs, ${ }^{34}$ the OECD Guidelines also provide that MNEs refrain from seeking or accepting exemptions not otherwise contemplated in the regulatory framework with regards to human rights, as a mechanism to reduce possible adverse impacts. ${ }^{35}$

- Criteria used by host countries seeking to attract particularly desirable FDI. ${ }^{36}$ A few examples of types of projects and industries that certain host countries consider particularly desirable were provided earlier, in the context of the quality-of-investment discussion. Net-benefit tests or environmental and social impact assessments also provide pointers that are relevant in the context of identifying sustainable FDI characteristics. Beyond that, the Thailand Board of Investment, Australia's Foreign Investment Policy and Namibia's Investment Promotion Act 2016 mention the enhancement of national competitiveness by encouraging research and development, innovation and value creation in the agricultural, industrial and services sectors, small and medium-size enterprises, fair competition, and inclusive growth; ${ }^{37}$ transparent regulation and supervision

29 This note also briefly discusses the OECD's Due Diligence Guidance.

30 Office of the High Commissioner for Human Rights, The UN Principles on Business and Human Rights (United Nations 2011) Principle 11 <http://www.ohchr.org/Documents/ Publications/GuidingPrinciplesBusinessHR_EN.pdf> accessed 13 April 2018.

$31 \quad$ ILO (n 19) Principle 44.

32 OECD, Guidelines for Multinational Enterprises (OECD 2011) ch IX (5) <http://oecd.org/ daf/inv/mne/48004323.pdf> accessed 13 April 2018.

33 UNCTAD, 'Investment Policy Framework for Sustainable Development' (United Nations 2015) $14<$ http://unctad.org/en/PublicationsLibrary/diaepcb2015d5_en.pdf> accessed 13 April 2018.

34 OECD (n 32$) \operatorname{ch~II~(10).~}$

35 ibid ch II (5).

36 Many countries have laws and regulations referring to contributions that international investors can make to the national economy. Six host countries were selected from among developed countries, seven from Asian countries, five from African countries, and two from Latin American countries, for a total of 20.

37 Thailand Board of Investment, 'Policies for Investment Promotion' (2015) <http://boi .go.th/index.php?page=policies_for_investment_promotion> accessed 13 April 2018. 
of investors as well as ensuring a fair return to the people; ${ }^{38}$ and the promotion of local linkages and increasing employment creation. ${ }^{39}$

- Criteria used by home countries that support their firms investing abroad and that make such support dependent on meeting certain conditions. ${ }^{40}$ The United States' Overseas Private Investment Corporation, the United Kingdom's Department for International Development (including the Commonwealth Development Corporation guidance for fund managers on respect for human rights $)^{41}$ and Proparco, the private sector financing arm of France's Agence Française de Développement, stipulate the following requirements: avoiding prejudice and discrimination and respect for human rights; ${ }^{42}$ promoting good health and nutrition; ${ }^{43}$ and respecting working conditions and the rights of workers. ${ }^{44}$ Chinese Guidelines encourage MNEs to take into account the impacts of their activities on the environment and to take measures to mitigate possible adverse impacts. ${ }^{45}$

- Standards of intergovernmental organizations. ${ }^{46}$ The International Financial Corporation and the Safeguard Policy Statement of the Asian

38 Foreign Investment Review Board (FIRB), 'Australia's Foreign Investment Policy' (September 2016) <https://firb.gov.au/files/2015/og/Australias-Foreign-InvestmentPolicy-2016-2017.pdf > accessed 13 April 2018.

39 Namibia Investment Promotion Act (n 6) s 14(d)-(g).

40 Not many home countries have such conditions in place. Karl P Sauvant and others, 'Trends in FDI, Home Country Measures and Competitive Neutrality' in Andrea K Bjorklund (ed), Yearbook on International Investment Law \& Policy 2012-2013 (OUP 2014) $3^{-107}$. Thirteen such standards were examined.

41 Commonwealth Development Corporation, 'Code of Responsible Investing' (March 2017) <https://assets.cdcgroup.com/wp-content/uploads/2018/10/29104330/Code_of_ Responsible_Investing_March_2017_UPDATE31.pdf> accessed 18 October 2019.

42 United States Overseas Private Investment Corporation, 'Environmental and Social Policy Statement' (January 2017) s 1.3 <https://opic.gov/sites/default/files/files/final\%20 revised\%2oESPS\%2001132017(1).pdf> accessed 13 April 2018.

43 United Kingdom, Department for International Development, 'Economic Development Strategy: Prosperity, Poverty and Meeting Global Challenges' (January 2017) $13<$ https:// gov.uk/government/uploads/system/uploads/attachment_data/file/587374/DFID -Economic-Development-Strategy-2017.pdf> accessed 13 April 2018.

44 Proparco, Groupe Agence Française de Développement, 'E\&S Risk Assessment' < https:// proparco.fr/fr/rse > accessed 13 April 2018.

45 Ministry of Commerce, and Ministry of Environmental Protection of the People's Republic of China, 'Notification of the Ministry of Commerce and the Ministry of Environmental Protection on Issuing the Guidelines for Environmental Protection in Foreign Investment and Cooperation' (18 February 2013) art 9 <http://english.mofcom.gov.cn/article/policyre lease/bbb/201303/20130300043226.shtml> accessed 13 April 2018.

46 Nine such standards of leading intergovernmental organisations/institutions were examined, including the standards of the regional development banks and those of the 
Development Bank require the protection of community health and safety ${ }^{47}$ and environmental impact assessments and managing or minimizing involuntary resettlements as specific safeguard requirements to be satisfied during project preparation and implementation. ${ }^{48}$ The Asian Infrastructure Investment Bank's Environmental and Social Policy Framework goes beyond the above to include labour, gender equality, community engagement, and specific provisions on climate change. ${ }^{49}$

- Voluntaryglobal business codes of international business organizations. ${ }^{50}$ The International Chamber of Commerce (ICC) Guidelines for International Investment and the Voluntary Principles on Security and Human Rights mention (among others) the following: to educate, train, and motivate employees to conduct their activities in an environmentally responsible manner ${ }^{51}$ and respect for human rights in security arrangements for projects. ${ }^{52}$

- Voluntary standards of private institutional investors. ${ }^{53}$ Boston Common Asset Management, ACTIAM and Domini provide for the promotion of

International Finance Corporation, the Multilateral Investment Guarantee Agency, the World Bank, and the Global Compact.

47 International Finance Corporation (IFC), 'IFC Performance Standards on Environmental and Social Sustainability' (World Bank Group, 1 January 2012) Performance Standard 4 <https://ifc.org/wps/wcm/connect/co2c2e86-e6cd-4b55-95a2-b3395d204279/IFC_ Performance_Standards.pdf?MOD=AJPERES\&CVID=kTjHBzk> accessed 13 April 2018.

48 Asian Development Bank, Policy Paper, 'Safeguard Policy Statement' (June 2009) Safeguards 1 and 2 <https://adb.org/sites/default/files/institutional-document/32056/ safeguard-policy-statement-june20o9.pdf > accessed 13 April 2018.

49 Asian Infrastructure Investment Bank, 'Environmental and Social Policy Framework' (February 2016) $4-5$ <https://aiib.org/en/policies-strategies/_download/environmentframework/20160226043633542.pdf > accessed 13 April 2018.

5o Four such codes were examined, including the 'Guidelines for International Investments' of the International Chamber of Commerce, the most comprehensive of these codes.

51 ICC, 'ICC Guidelines for International Investment' (2016) VII (1) (g) <https://cdn.iccwbo .org/content/uploads/sites/3/2017/o1/ICC-Guidelines-For-International-Investment-2016 .pdf $>$ accessed 13 April 2018.

$5^{2}$ Voluntary Principles on Security and Human Rights, 'Voluntary Principles on Security and Human Rights' (2000) <http://voluntaryprinciples.org/what-are-the-voluntary -principles/> accessed 13 April 2018.

53 The list of the top 20 active signatories of the Principles for Responsible Investment (PRI) as identified in its Annual Report 2016 served as the basis of the analysis. United Nations PRI webpage, 'What Are the Principles for Responsible Investment?' < https://unpri.org/ about-the-pri/what-are-the-principles-for-responsible-investment/323.article> accessed 18 October 2019. The PRI are internationally recognized principles for responsible investments; among its signatories are leading asset owners and assets managers. While the PRI represent an independent effort, they are supported by two United Nations agencies: the United Nations Environment Programme Finance Initiative and the Global Compact. 
economic development programmes that benefit women, minorities or economically disadvantaged groups; ${ }^{54}$ pollution controls and prevention of biodiversity loss; ${ }^{55}$ and their commitment to workplace safety. ${ }^{56}$

- Voluntary industry codes. ${ }^{57}$ The International Council on Mining and Metals' Ten Principles for sustainable mining, the Standard for Sustainable and Resilient Infrastructure, the Equator Principles, and the United Nations' Principles for Responsible Investment provide for minimizing involuntary resettlement and fair compensation; ${ }^{58}$ environmental, social and governance reporting; ${ }^{59}$ the lowering of greenhouse gas emissions; ${ }^{60}$ and meeting expectations relating to environmental and social governance issues for service providers. ${ }^{61}$

- Voluntary company codes. ${ }^{62}$ The codes of Apple (United States), BP (United Kingdom), Tata Motors (India), China National Petroleum

Given its universal recognition among institutional investors, the PRI were used as a frame of reference to identify the four most active institutional investors with specific standards with regards to responsible investment for this article.

54 Boston Common Asset Management, 'Boston Common Comprehensive ESG Sustainability Criteria' (2016) 3 <http://news.bostoncommonasset.com/wp-content/ uploads/2016/og/Boston-Common-Comprehensive-ESG-Criteria.pdf> accessed 13 April 2018.

55 ACTIAM, 'Fundamental Investment Principles - Companies' (2017) 3.4 <https://actiam .nl/nl/documenten/verantwoord/Documents/Fundamental_Investment_Principles_ Companies.pdf> accessed 13 April 2018.

56 Domini, 'Impact Investment Standards' (2016) no $25<$ https://domini.com/sites/default/ files/_files/Impact_Investment_Standards.pdf > accessed 13 April 2018.

57 Fourteen such codes were reviewed, based primarily on the list of the instruments and initiatives compiled for the updating of the OECD Guidelines for Multinational Enterprises, as included in a resource document compiled by the OECD. OECD, 'The OECD Guidelines for Multinational Enterprises: Reference Instruments and Initiatives Relevant to the Updated Guidelines' (March 2012) <http://oecd.org/daf/inv/mne/ ResourceDocumentWeb.pdf>.

$5^{8}$ International Council on Mining and Metals, 'Sustainable Development Framework: ICMM Principles' (Revised 2015) Principle $3<$ https://icmm.com/website/publications/ pdfs/commitments/revised-2015_icmm-principles.pdf> accessed 13 April 2018.

59 Equator Principles, 'The Equator Principles' (June 2013) $5^{-6}<$ http://equator-principles. com/wp-content/uploads/2017/03/equator_principles_III.pdf> accessed 13 April 2018.

6o SuRe, 'The Standard for Sustainable and Resilient Infrastructure v 0.3' (27 July 2016) para 3.1.1 <http://gib-foundation.org/content/uploads/2017/01/SuRevo.3final.pdf> accessed 13 April 2018.

61 United Nations, 'Principles for Responsible Investment' (2006) principle $4<$ https://www .unpri.org/about/the-six-principles > accessed 13 April 2018.

62 The global codes of 25 MNEs ( 12 headquartered in developed countries, 12 in developing countries, and one in an economy in transition) were examined, based on the following two UNCTAD lists: 'The World's Top 100 Non-Financial MNEs', ranked by foreign assets, 2015; and 'The Top 100 Non-Financial MNEs from Developing and Transition Economies', ranked by foreign assets, 2014, available from UNCTAD's website <http://unctad.org/en/ 
Corporation (China), and Petrobras (Brazil) provide for supply chain control and standards; ${ }^{63}$ responsible tax practices and avoidance of artificial tax arrangements; ${ }^{64}$ the economic development of communities in host countries; 65 support for local industrial development and preferential purchase and use of local products and services; ${ }^{66}$ and the protection of labour rights. ${ }^{67}$

- Voluntary models and codes of non-governmental organizations (NGOs). ${ }^{68}$ For example, the International Institute for Sustainable Development (IISD) Model Agreement on Investment for Sustainable Development and the Amnesty International Human Rights Principles for Companies mention the contribution to the development objectives of host countries ${ }^{69}$ and promoting and upholding human rights standards. ${ }^{70}$

While the $15^{\circ}$ instruments dealing with the relationship of host country governments and MNEs analyzed for this article are not necessarily representative of the universe of instruments dealing with this relationship, they

Pages/Home.aspx> accessed 13 April 2018. The companies on these lists were compared against the members of the World Business Council for Sustainable Development and the members of the United Nations Global Compact, as these members are leaders on issues relating to sustainable development. In the end, the top five companies from each of North America. Latin/South America, Europe, Asia, and Africa were selected for review of their global corporate social responsibility/sustainable development policies.

63 Apple Inc, 'Supplier Responsibility Standards' (January 2017) 92-102 <https://images .apple.com/supplier-responsibility/pdf/Apple-Supplier-Responsible-Standards.pdf> accessed 13 April 2018.

64 BP PLC, 'BP's Approach to Tax' (2018) 2 <https://bp.com/content/dam/bp/business -sites/en/global/corporate/pdfs/sustainability/group-reports/bp-approach-to-tax-2018 .pdf $>$ accessed 18 October 2019.

65 Tata Group, 'Tata Code of Conduct' (effective 29 July 2015) Core Principle $3<$ https://tata .com/content/dam/tata/pdf/Tata\%20Code\%20Of\%2oConduct.pdf $>$ accessed 18 October 2019.

66 China National Petroleum Corporation, 'Environment and Society (Local Development)' <http://cnpc.com.cn/en/local/common_index.shtml> accessed 13 April 2018.

67 Petrobras, 'Social Responsibility Policy' <http://www.petrobras.com.br/en/society-and -environment/society/social-responsibility-policy/> accessed 13 April 2018.

68 The two principal models of this stakeholder group were examined, including the 'Model International Agreement on Investment for Sustainable Development' prepared by the International Institute for Sustainable Development.

69 Howard Mann and others, 'IISD Model Agreement on Investment for Sustainable Development' (April 2005) (IISD) art 11(c) <https://iisd.org/pdf/2005/investment_model_ int_agreement.pdf $>$ accessed 13 April 2018.

70 Amnesty International, 'Human Rights Principles for Companies' (January 1998) ACT 70/01/98 4-5 <https://amnesty.org/download/Documents/1480oo/act700011998en.pdf> accessed 13 April 2018. 
do capture a wide range of instruments across key stakeholder groups in the FDI space. Therefore, they are indicative of what seems to be emerging regarding the contributions international investors are expected to make - or they themselves expect to make - to host countries' development. Moreover, many of the instruments in these various categories were most likely formulated in the knowledge of similar instruments and, therefore, might well build on each other to a certain extent. Finally, it should be noted that the instruments were not 'weighted'; in other words, for the purpose of this analysis, it does not matter whether a contribution was mentioned in, say, an IIA or an industry code, as the objective is to identify what principal stakeholders regard as contributions to a host country's development.

These contributions were subsequently grouped as 'characteristics' (some representing an aggregation of various more specific characteristics), as set out in Table 1, under the four dimensions of the definition of 'sustainable FDI': economic development, social development, environmental development, and governance, and for each of the stakeholder groups mentioned above. These dimensions and characteristics do not reflect water-tight divisions. Indeed, many of them overlap and many are mutually inter-dependent. ${ }^{71}$

Finally, it should be noted that the list of FDI sustainability characteristics emerging from this research is deliberately characterized as 'indicative'. The reason is that, determining what kind of commercially viable investment makes a maximum contribution to the economic, social and environmental development of a host country and takes place in the framework of fair governance mechanisms depends on a number of variables. Most important among them are the development strategy pursued by a given host country and the priorities it establishes, as well as the level of development of a host country, the sector in which an investment takes place, the size of a project, and

71 Human rights issues form a more unique challenge for categorization purposes, given a broad overlap in many instances between human rights and social, economic and environmental development. Labour rights are human rights, as is non-discrimination, the right to fair wages, indigenous people's rights, gender equality rights, and various rights related to resettlement and cultural heritage, the right to a clean environment, to economic development, and so on. In addition, human rights due diligence mechanisms have to cover many issues outside the human rights listed here. At the same time, not all of the sustainability characteristics fall within a human rights framework. On the other hand, those who approach responsible investment issues starting from a human rights perspective generally rely on a different type of categorization in their analyses, often-time more legally based than based on a sustainable development analysis. But these approaches are not in any type of competition. Thus, and bearing in mind that the categories used here are not meant to suggest water-tight divisions, these analyses are complementary and hopefully mutually supportive. 
TABLE 1 The Dimensions of Sustainable FDI and Their Sustainability Characteristics

Characteristic $^{\mathrm{a}}$

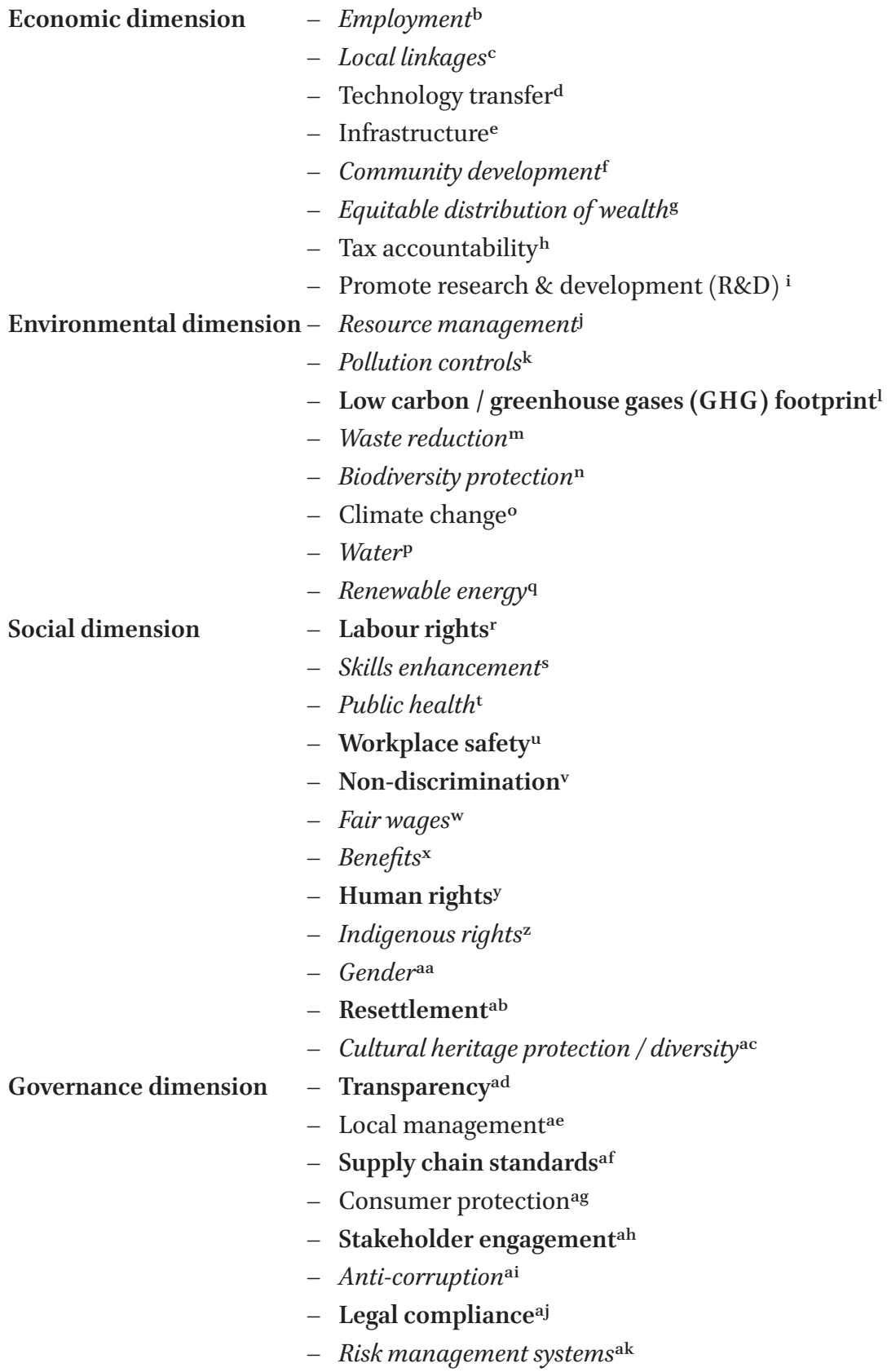$$
\text { - Promote research \& development }(\mathrm{R} \& D)^{\mathrm{i}}
$$

Environmental dimension - Resource management ${ }^{j}$

- Pollution controls ${ }^{\mathrm{k}}$

- Low carbon / greenhouse gases (GHG) footprint ${ }^{1}$

- Waste reduction $^{\mathrm{m}}$

- Biodiversity protection ${ }^{\mathrm{n}}$

- Climate change ${ }^{\circ}$

- Waterp

Social dimension

- Renewable energy ${ }^{\mathrm{q}}$

- Labour rights ${ }^{\mathrm{r}}$

- Skills enhancement ${ }^{\text {s }}$

- Public health ${ }^{\mathrm{t}}$

- Workplace safety

- Non-discrimination ${ }^{\mathrm{v}}$

- Fair wagesw

- Benefits ${ }^{\mathrm{x}}$

- Human rights ${ }^{\mathrm{y}}$

- Indigenous rights ${ }^{\mathrm{z}}$

- Genderaa

- Resettlement ${ }^{\mathrm{ab}}$

- Cultural heritage protection / diversity ${ }^{\mathrm{ac}}$

Governance dimension - Transparency ${ }^{\text {ad }}$

- Local management ${ }^{\mathrm{ae}}$

- Supply chain standards ${ }^{a f}$

- Consumer protection ${ }^{\text {ag }}$

- Stakeholder engagement ${ }^{\text {ah }}$

- Anti-corruption ${ }^{\text {ai }}$

- Legal compliance ${ }^{\text {aj }}$

- Risk management systems ${ }^{\mathrm{ak}}$ 


\section{Characteristic}

- Environmental management systems ${ }^{a l}$

- Environmental impact assessment / social impact assessment $^{\text {am }}$

- Human rights due diligence ${ }^{\text {an }}$

- Corporate governance ${ }^{\text {ao }}$

SOURCE: Independent research conducted for this article and table designed by the authors.

a Bolded characteristics are common characteristics and italicized characteristics are emerging common characteristics, as defined in the text below.

b Job creation in the host country.

c Linkages with the local economy, such as procurement from local suppliers.

d Includes provisions that require MNEs to transfer technology to the host country, domestic partners in the host country etc.

e Obligations on MNEs to develop / build infrastructure in host countries.

f Relating to commitments by MNEs to provide financial or other support for the development of communities in a host country.

g Includes, for example, references like in Paragraph 42 of the ILO MNE Declaration: 'Governments, especially in developing countries, should endeavour to adopt suitable measures to ensure that lower income groups and less developed areas benefit as much as possible from the activities of multinational enterprises'.

$\mathrm{h}$ Including, for example, the obligation of MNEs to comply with tax laws or to prevent tax avoidance.

i Relating to commitments by MNEs to undertake research and development activities in the host country.

j Relates to the conservation of resources or other preservation techniques for the protection of resources.

$\mathrm{k} \quad$ Includes obligations on MNEs to undertake their activities with due regard to reducing pollution etc.

l Reducing emission of greenhouse gases / carbon emissions.

$\mathrm{m} \quad$ Includes reducing waste generation as well as management of disposal of waste.

$\mathrm{n} \quad$ Includes protection of natural habitats, species and other biodiversity.

o Includes climate change related adaptation plans.

p Includes water pollution control, but also water uses, water allocation and water quantity issues, including ongoing technology processes to minimize water use on a continuing basis.

q Includes, among other things, the use of renewable energy in products and services or promotion of use of renewable energy in its activities.

$\mathrm{r}$ Includes, among others, freedom of association and the effective recognition of the right to collective bargaining; the elimination of all forms of forced or compulsory labour; and the effective abolition of child labour.

s Includes, among others, skills development of workers to allow them to access better work opportunities. 
t Relates to all aspects of the health of communities and commitments on the behalf of MNEs to adhere to laws relating to protection of health of communities in a host country.

$\mathrm{u} \quad$ Relates to health and safety of workers.

v Relates to commitment by MNEs to undertake their activities in a non-discriminatory manner etc. Includes obligations to pay minimum wages according to national laws, fair wages according to international conventions etc.

$\mathrm{x} \quad$ Includes pension plans, other employee and social security benefits.

$\mathrm{y} \quad$ Includes adhering to international human rights standards.

$\mathrm{z} \quad$ Includes issues such free, prior and informed consent of indigenous communities.

aa Includes issues relating to women participation in community engagements, equal opportunities to participate in the workforce, access to land rights, specific problems associated with women's access to utilities, etc.

ab In addition to aspects relating to the minimization of resettlement, this characteristic also includes other important elements about how to do so, establishing compensation levels, whose responsibility it is, etc.

ac Relates to protection / preservation of local culture, cultural artifacts etc.

ad Includes aspects related to disclosure of information (relating to tax payments, supply chain due diligence, contracts, corporate governance practices, human rights, etc.) by MNEs.

Includes, for example, the presence of local management and references such as the one contained in art 12(2) of the Peru-Japan Free Trade Agreement that provides: '[a]Party may require that a majority of the board of directors, or any committee thereof, of an enterprise of that Party that is a covered investment, be of a particular nationality, or resident in the territory of the Party, provided that the requirement does not materially impair the ability of the investor to exercise control over its investment'.

af Includes aspects relating to sustainable and responsible business practices vis-à-vis ethics, labour, health, and safety, diversity, and the environment for supply chains of MNEs.

ag Includes, for example, no false or misleading advertisements.

ah Includes consultations with communities' related aspects.

ai Includes compliance with corruption related laws, provisions against bribery of public officials etc.

aj Relates to compliance with the laws and standards promulgated by host countries.

ak Includes, for example, Honda's Risk Management Policy (Honda is one of the companies reviewed in this research), which includes, eg, aspects such as risk analysis and risk management structures within the group.

al Refers to ongoing management frameworks for handling any environmental issues related to an investment or project.

am Assessment procedures/framework mandated for investment or projects at inception.

an Includes processes to identify, prevent and address impacts on human rights.

ao Includes aspects such as transparency, accounting practices and corporate accountability. Does not include aspects related to board processes or executive compensation. 
the underlying motivation for which a firm makes an investment (market-, efficiency-, resource-, asset-seeking); ${ }^{72}$ moreover, the impact of an investment might change over time.

To elaborate on the last two of these factors (and beginning with the first), each of the underlying motivations of an investment can lead to more or less of an impact on a host country's sustainable development. In the case of market-, efficiency- and resource-seeking investment, for example, linkages can be created and training can be imparted, even if this potential is likely to be considerable less extensive in the case of efficiency-seeking FDI than in the case of market-seeking FDI. Even in the case of asset-seeking FDI (and assuming it does not lead to a closure of a facility), the contribution of a continuing investment can, potentially, be higher than it was in the past. In either case, furthermore, the strategy of the parent company and its behaviour, as well as the policies of the host country, determine to a large extent the contribution to sustainable development. This, in turn, draws attention to the temporal dimension of an investment and its impact. Thus, in the case of a large-scale mining project, the governance mechanism specified in the contract governing that project determines the distribution and nature of benefits accruing to the investor and the host country even before an investment is being made. On the other hand, it may take time to create linkages in the case of any new investment. The temporal dimension, furthermore, interacts with the type of FDI: efficiency-seeking FDI may simply not stay long enough to have a sustained impact, while FDI that remains in a host country for many years can be expected to have more of an impact.

Governments need to be aware of the various variables that influence the contributions that FDI can make to the development of host countries, including the differentiated impact of the various types of FDI at the time an investment is made and that this impact - and an investor's underlying motivations and strategy - can change over time. Hence, governments need to tailor their expectations and policies accordingly, including by pursuing policies that encourage investments to become firmly integrated into, and committed to, the host country. At the same time, host country governments typically must consider trade-offs among various characteristics. A classic trade-off has been employment and the generation of income for environmental concerns, as one sees in the development of heavy oil sands or deforestation to establish agricultural plantations. The viability of such tradeoffs for the future, however, is now in more doubt than ever if the SDGs are to be met.

72 John H Dunning and Sarianna M Lundan, Multinational Enterprises and the Global Economy (Edward Elgar 2008) 67-74. 
The discussion of the research on FDI sustainability characteristics that follows goes beyond a simple statistical analysis: it seeks to place the evolution of these characteristics in the broader context of the global understanding of what sustainable development requires. Looking at the characteristics in this context, the analysis suggests that their evolution broadly mirrors a similar evolution of global development and environment policies.

Historically, global development policy manifested itself in the United Nations' programmes adopted for the Development Decades. Parallel to that, the discussion of environmental issues began with the 1972 United Nations Conference on the Human Environment. The Earth Summit in Rio de Janeiro in 1992 (United Nations Conference on Environment and Development (UNCED)) set out, for the first time, a global agenda on sustainable development, followed by the declaration of the Millennium Development Goals (MDGs) in 2000 and the World Summit on Sustainable Development in Johannesburg in 2002. In 2015, then, the United Nations General Assembly adopted the SDGs. The adoption of the MDGs and SDGs merged the separate strands of development and environment discussions and actions into the sustainable development agenda, a holistic set of economic, social and environmental goals.

The FDI sustainability characteristics (see Table 1) identified in the research undertaken for this article broadly show a similar trajectory over time, with economic and social characteristics now appearing more frequently, and with more depth and texture, in the instruments reviewed. While they remain less represented overall, the timelines show a direction towards this more holistic conception.

The quantitative analysis of the various instruments is summarized in Figure 1, 'Matrix of sustainability characteristics of FDI,' setting out the sustainability characteristics against groupings of instruments for each of the dimensions of the sustainable FDI definition presented in this article. ${ }^{73}$

73 In delineating the groupings for the quantitative analysis reflected in the subsequent tables, the two instruments prepared by NGOs were not included. The reasons are twofold: for one, there are only two broadly based NGO instruments; adding in more specific instruments would be a very broad exercise. Second, non-business NGOs are generally strongly supportive of the SDGs and, if anything, urge that foreign investors make a maximum contribution to the advancement of the SDGs (although they may focus on the subject matters of specific interest to them). Casting a broad net, therefore, would have risked distorting the findings from other instruments. The results reported here demonstrate empirically the growing extent to which all stakeholders engaged in this area are adopting instruments that increasingly reflect what might previously have been seen to be simply NGO positions. Furthermore, it should be noted that, in undertaking the 
FIGURE 1 Matrix of sustainability characteristics of FDI: by (a) economic, (b) environmental, (c) social and (d) governance dimension, group of instruments and characteristic

a. Economic Dimension of Sustainable FDI

\begin{tabular}{|c|c|c|c|c|c|c|c|c|}
\hline Key & \multirow[b]{6}{*}{$\varliminf_{\Xi}^{\infty}$} & \multirow{6}{*}{ 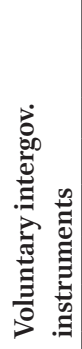 } & \multirow{6}{*}{ 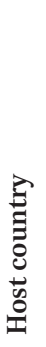 } & \multirow{6}{*}{ 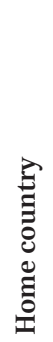 } & \multirow{6}{*}{ 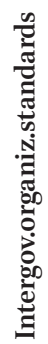 } & \multirow{6}{*}{ 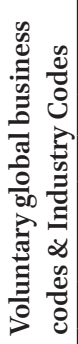 } & \multirow{6}{*}{ 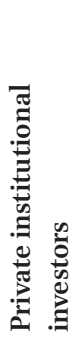 } & \multirow{6}{*}{ 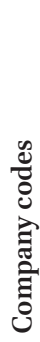 } \\
\hline $0 \%$ & & & & & & & & \\
\hline $1 \%-33 \%$ & & & & & & & & \\
\hline $34 \%-66 \%$ & & & & & & & & \\
\hline $67 \%-99 \%$ & & & & & & & & \\
\hline $100 \%$ & & & & & & & & \\
\hline \multicolumn{9}{|c|}{ General reference only } \\
\hline \multicolumn{9}{|l|}{ Employment } \\
\hline \multicolumn{9}{|l|}{ Local linkages } \\
\hline \multicolumn{9}{|l|}{ Technology transfer } \\
\hline \multicolumn{9}{|l|}{ Infrastructure } \\
\hline \multicolumn{9}{|c|}{ Community development } \\
\hline \multicolumn{9}{|c|}{ Equitable distrib. of wealth } \\
\hline \multicolumn{9}{|l|}{ Tax accountability } \\
\hline \multicolumn{9}{|l|}{ Promote R\&D } \\
\hline \multicolumn{9}{|c|}{ General and specific indicator } \\
\hline General or specific & & & & & & & & \\
\hline
\end{tabular}

analysis of the instruments, it might well be that some sustainability characteristics were overlooked in some of these instruments. If this should have occurred, it would make the results more robust. 
b. Environmental Dimension of Sustainable FDI

\begin{tabular}{|c|c|c|c|c|c|c|c|c|}
\hline Key & & & & & 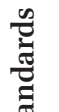 & 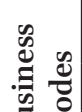 & & \\
\hline o\% & & & & & w & ق & $\overparen{\pi}$ & \\
\hline $1 \%-33 \%$ & & 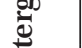 & & & $\cdot \stackrel{N}{\exists}$ & 疍 & 苯 & $\stackrel{8}{2}$ \\
\hline $34 \%-66 \%$ & & $\Xi \stackrel{\mathscr{\Xi}}{\Xi}$ & $E$ & $\stackrel{\Xi}{\Xi}$ & 0 & bo & 莺 & 8 \\
\hline $67 \%-99 \%$ & & छ छ & ठె & ¿ & 官 & के & . & $\widehat{\Xi}$ \\
\hline $100 \%$ & $\stackrel{\infty}{\Xi}$ & 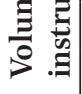 & 蓠 & 苛 & $\stackrel{\Xi}{\Xi}$ & $\frac{\Xi}{\Xi}$ &. & छे \\
\hline General reference & & & & & & & & \\
\hline Resource manage & & & & & & & & \\
\hline Pollution controls & & & & & & & & \\
\hline Low carbon foot & & & & & & & & \\
\hline Waste reduction & & & & & & & & \\
\hline Biodiversity protec & & & & & & & & \\
\hline Climate change & & & & & & & & \\
\hline Water & & & & & & & & \\
\hline Renewable energy & & & & & & & & \\
\hline General and spec & & & & & & & & \\
\hline General or specifi & & & & & & & & \\
\hline
\end{tabular}




\section{c. Social Dimension of Sustainable FDI}

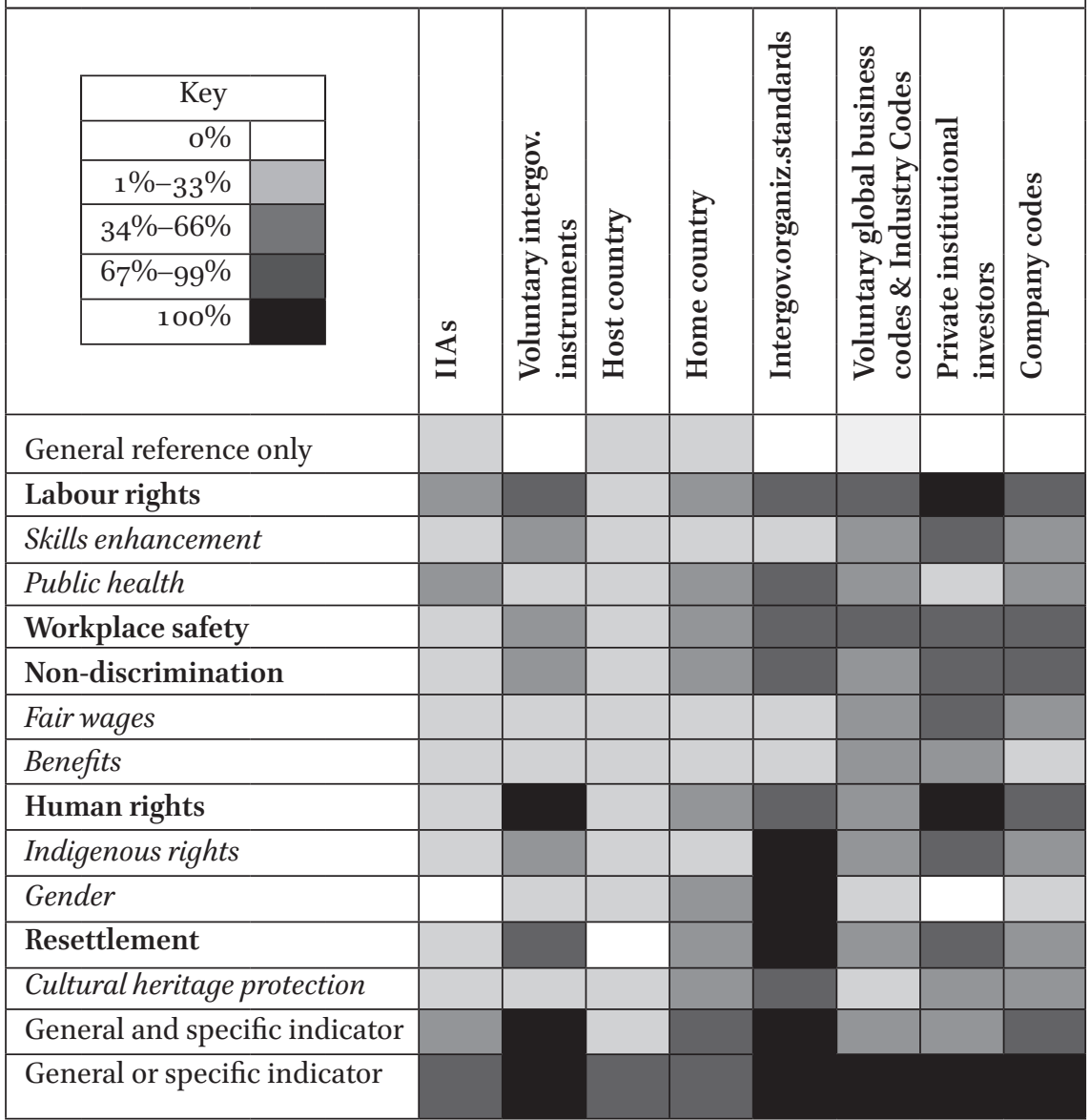




\section{d. Governance Dimension of Sustainable FDI}

\begin{tabular}{|c|c|c|c|c|c|c|c|c|}
\hline Key & \multirow[b]{6}{*}{$\leqq$} & \multirow{6}{*}{ 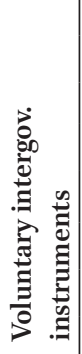 } & \multirow{6}{*}{ 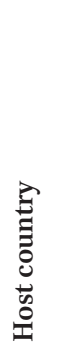 } & \multirow{6}{*}{ 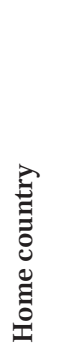 } & \multirow{6}{*}{ 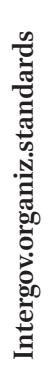 } & \multirow{6}{*}{ 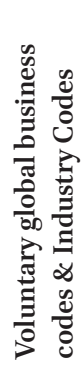 } & \multirow{6}{*}{ 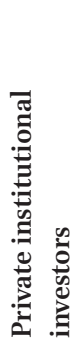 } & \multirow{6}{*}{ 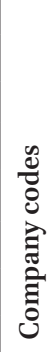 } \\
\hline $0 \%$ & & & & & & & & \\
\hline $1 \%-33 \%$ & & & & & & & & \\
\hline $34 \%-66 \%$ & & & & & & & & \\
\hline $67 \%-99 \%$ & & & & & & & & \\
\hline $100 \%$ & & & & & & & & \\
\hline General reference o & & & & & & & & \\
\hline Transparency & & & & & & & & \\
\hline Local management & & & & & & & & \\
\hline Supply chain stand & & & & & & & & \\
\hline Consumer protectic & & & & & & & & \\
\hline Stakeholder engag & & & & & & & & \\
\hline Anti-corruption & & & & & & & & \\
\hline Legal compliance & & & & & & & & \\
\hline Risk-management s & & & & & & & & \\
\hline $\begin{array}{l}\text { Environmental mar } \\
\text { systems }\end{array}$ & & & & & & & & \\
\hline Environ./social asse & & & & & & & & \\
\hline Human rights dilige & & & & & & & & \\
\hline Corporate governar & & & & & & & & \\
\hline General and specifi & & & & & & & & \\
\hline General or specific & & & & & & & & \\
\hline
\end{tabular}

SOURCE: Independent research conducted for this article; table designed by the authors. NOTE: Bolded characteristics are common characteristics and italicized characteristics are emerging common characteristics, as defined in the text below. 'Key' refers to the percentage of instruments that mention a given characteristic. 'General reference only' refers to a situation in which an instrument contains only a reference to, for example, the promotion of economic development - a general reference. 'General and specific indicators' refers to a situation in which an instrument contains a reference to, for example, the promotion of economic development and, in addition, specifies, for example, the creation of local linkages. 'General or specific indicator' refers to a situation in which an instrument contains either a general reference or a specific reference; this indicator is therefore the most comprehensive one. 
As an inspection of Figure 1 reveals, each of the four dimensions of sustainable FDI are strongly present in the great majority of the instruments that were examined, either by way of a general or specific reference. More specifically, at least two-thirds of the instruments of seven of the eight stakeholder groups mention economic and environmental sustainability, and at least twothirds of the instruments of all stakeholder groups mention the social and governance dimensions. The social, environmental and governance dimensions receive particular attention, reflecting the evolution of the issue discussed at the beginning of this section. In any event, this shows a high level of awareness and inclusiveness of the various dimensions of sustainable FDI.

Moving from the level of the four dimensions of sustainable FDI to the more specific level of individual sustainability characteristics, Figure 1 reveals that every one of the sustainability characteristics listed in that figure is mentioned by at least three stakeholder groups and, therefore, could be part of an indicative list of FDI sustainability characteristics. This may be helpful as, in the end, it is for stakeholders to decide which characteristics are most important for them to advance sustainable development in the context of specific projects.

Moreover, as Figure 2 suggests, it appears that, over time, additional characteristics have emerged and/or have become more frequent. As indicated above, this broadly tracks the evolution of global policies on development and the environment. This is particularly obvious for the environmental and social dimensions of sustainable FDI, which have become more prominent reflecting the overall trend of the increased saliency of these issues in various instruments. Perhaps a surprising result is the attention given to employment, local linkages and technology transfer in instruments published prior to 2000.

Going beyond this broad analysis, it emerges that there are a number of sustainability characteristics that have a $5^{0}$ per cent or more coverage in at least four out of the eight categories of stakeholders/instruments. For example, at least half of the instruments related to home countries, intergovernmental organizations, private institutional investors, and companies mention the characteristic 'low carbon footprint'. These 'common FDI sustainability characteristics', which therefore can be seen as a core set of characteristics, are the following:

- Low carbon footprint

- Labour rights

- Workplace safety

- Non-discrimination

- Human rights

- Resettlement

- Transparency 
FIGURE 2 Matrix of sustainability characteristics of FDI, by (a) economic, (b) environmental, (c) social and (d) governance dimension and characteristic, over time

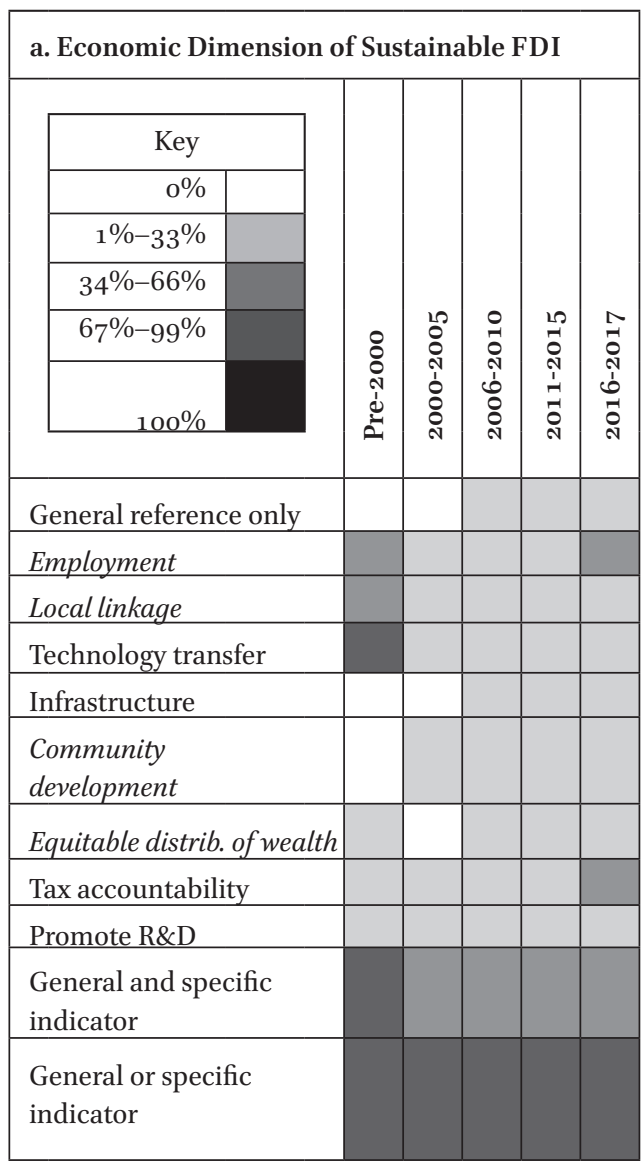

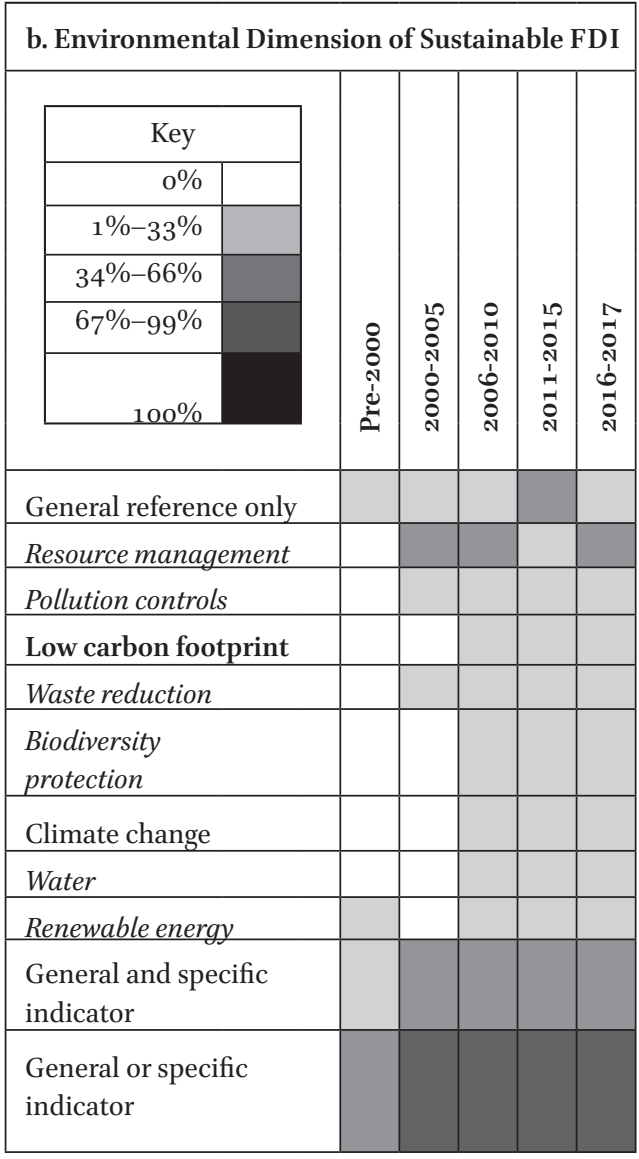




\begin{tabular}{|c|c|c|c|c|c|}
\hline \multicolumn{6}{|c|}{ c. Social Dimension of Sustainable FDI } \\
\hline & 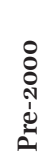 & 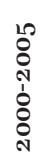 & 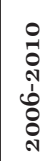 & 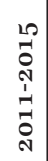 & 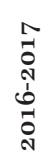 \\
\hline General reference only & & & & & \\
\hline Labour rights & & & & & \\
\hline Skills enhancement & & & & & \\
\hline Public health & & & & & \\
\hline Workplace safety & & & & & \\
\hline Non-discrimination & & & & & \\
\hline Fair wages & & & & & \\
\hline Benefits & & & & & \\
\hline Human rights & & & & & \\
\hline Indigenous rights & & & & & \\
\hline Gender & & & & & \\
\hline Resettlement & & & & & \\
\hline Cultural heritage protection & & & & & \\
\hline $\begin{array}{l}\text { General and specific } \\
\text { indicator }\end{array}$ & & & & & \\
\hline General or specific indicator & & & & & \\
\hline
\end{tabular}

\begin{tabular}{|c|c|c|c|c|c|}
\hline \multicolumn{6}{|c|}{ d. Governance Dimension of Sustainable FDI } \\
\hline & 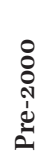 & 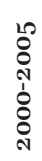 & 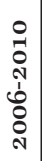 & 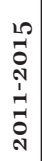 & 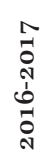 \\
\hline \multicolumn{6}{|l|}{ General reference only } \\
\hline \multicolumn{6}{|l|}{ Transparency } \\
\hline \multicolumn{6}{|l|}{ Local management } \\
\hline \multicolumn{6}{|l|}{ Supply chain standards } \\
\hline \multicolumn{6}{|l|}{ Consumer protection } \\
\hline \multicolumn{6}{|l|}{ Stakeholder engagement } \\
\hline \multicolumn{6}{|l|}{ Anti-corruption } \\
\hline \multicolumn{6}{|l|}{ Legal compliance } \\
\hline \multicolumn{6}{|l|}{ Risk-management systems } \\
\hline \multicolumn{6}{|l|}{$\begin{array}{l}\text { Environ. management } \\
\text { systems }\end{array}$} \\
\hline \multicolumn{6}{|l|}{ Environ./social assessment } \\
\hline \multicolumn{6}{|l|}{ Human rights diligence } \\
\hline \multicolumn{6}{|l|}{ Corporate governance } \\
\hline \multicolumn{6}{|l|}{$\begin{array}{l}\text { General and specific } \\
\text { indicator }\end{array}$} \\
\hline General or specific indicator & & & & & \\
\hline
\end{tabular}

SOU RCE: Independent research conducted for this article.

NOTE: This analysis excludes all company codes because most do not identify the date of publication. Similarly, Proparco (a home country standard) and Domini (a private investor standard) are excluded because they do not identify the date of publication. Because nine of the ten United Nations Global Compact principles were adopted in 2000, this year is used for that standard. The ICMM Ten Principles revision date of 2015 is utilized. 'Key' refers to the percentage of instruments that mention a given characteristic. 'General reference only' refers to a situation in which an instrument contains only a reference to, for example, the promotion of economic development - a general reference. 'General and specific indicators' refers to a situation in which an instrument contains a reference to, for example, the promotion of economic development and, in addition, specifies, for example, the creation of local linkages. 'General or specific indicator' refers to a situation in which an instrument contains either a general reference or a specific reference; this indicator is therefore the most comprehensive one. Bolded characteristics are common characteristics and italicized characteristics are emerging common characteristics, as defined in the text below. 
- Supply chain standards

- Stakeholder engagement

- Legal compliance.

Any stakeholder that would include any of these common FDI sustainability characteristics in any of their instruments could feel rather confident that these are widely accepted FDI sustainability characteristics. This conclusion is bolstered by the fact that different types of instruments, relating to different stakeholders in the field, include these common characteristics, meaning that these characteristics reflect not only the interests of a limited group of stakeholders and, therefore, make the consensus about their desirability stronger.

Beyond this group of common FDI sustainability characteristics, there are also a number of sustainability characteristics that are labeled here as 'emerging common FDI sustainability characteristics' (again in the sense of being increasingly widely accepted). These are characteristics that are present in at least one-third of the instruments examined in at least three of the eight categories of stakeholder instruments. For example, 33 per cent or more of the voluntary intergovernmental instruments, home country instruments and company codes identify 'local linkages' as a desirable FDI characteristic. As can be seen from Figure 1, there are quite a number of other sustainability characteristics that meet this threshold of being mentioned in at least onethird of the instruments by at least three of the stakeholder groups.

More specifically, these 'emerging common FDI sustainability characteristics' are the following:

\section{a. Economic}

- Employment

- Local linkages

- Community development

- Equitable distribution of wealth

b. Environmental

- Resource management

- Pollution controls

- Waste reduction

- Biodiversity protection

- Water

- Renewable energy

c. Social

- Skills enhancement

- Public health

- Fair wages

- Benefits

- Indigenous rights 
- Gender

- Cultural heritage protection

\section{d. Governance}

- Anti-corruption

- Risk-management systems

- Environmental/social assessment.

Interestingly, this threshold of one-third or more of the instruments by at least three of the stakeholder groups is reached most frequently in the social and environmental sustainability dimensions, followed closely by the economic dimension. Even this lower threshold indicates a relatively high awareness and broader acceptance of certain FDI sustainability characteristics by various stakeholder groups.

What is also noticeable is that none of the FDI sustainability characteristics in the economic sustainability dimension make it into the group of common sustainability characteristics (see Figure 1), though they figure more prominently among the emerging common FDI sustainability characteristics. This may reflect the fact that the instruments examined reflect, as discussed at the beginning of this section, a convergence of two historic trends, namely the development and environment discussions. Environmental issues, as well as governance and social issues, were particularly championed by developed countries and their civil societies (including trade unions). Since most of the instruments in the FDI space traditionally have reflected the views of developed countries and their civil societies, as well as the views of the business community, economic development issues typically received only general attention. With developing countries becoming more assertive, especially in the negotiation of IIAs, this picture is changing.

The general picture that emerges is of course influenced by a number of factors. To begin with, it needs to be recalled that only a selected number of instruments was scrutinized. Examining the full universe of instruments would likely yield additional characteristics and, therefore, a longer indicative list of FDI sustainability characteristics. Furthermore, additional instruments may also lead to a more frequent appearance of some of the characteristics already covered, potentially resulting in a higher percentage of instruments containing these characteristics and, therefore, moving the classification of these characteristics from, say, the 1-33 per cent range of coverage to the 34-66 per cent range. This is especially likely if additional instruments were tilted more towards newer instruments, given the general trends shown in Figure 2. (But, of course, the opposite could also be the case - especially if additional older instruments were included in the analysis - namely, if these additional instruments were not to contain some of the characteristics.) Finally, a number of 
the instruments examined are not of a general nature but rather issue specific, industry specific or company specific. For example, the Voluntary Principles on Security and Human Rights deal with safety and security principles that encourage respect for human rights and are designed specifically for extractive sector companies. In these instances, certain sustainability characteristics may not be relevant to the industries or companies involved and, therefore, skew the picture in favour of one sustainability dimension or another (or may simply be not mentioned often enough to enter the common or emerging FDI sustainability characteristics categories).

This last consideration is particularly obvious if one looks at the three instruments adopted by the United Nations on business and human rights, the ILO on social policy and the OECD on responsible business conduct in general (see Figure 3). Among these three, the first two are subject specific (i.e., they deal, respectively, with human rights and social issues), while the third one spans the entire range of expectations that governments have vis-à-vis foreign investors, providing, in a sense, cross-cutting standards that constitute a chapeau for various other standards. The most substantial overlap among these three instruments can be found in the economic, social and governance dimensions. Importantly, the three instruments together complement and supplement each other; they cover a wide range of sustainability characteristics; and they are relatively strong, as they reflect a broad consensus among governments. Interestingly, moreover, there is also a substantial overlap with the ICC Guidelines, suggesting a broad-based consensus between governments on the one hand and the global business community on the other as regards the contributions FDI and MNEs can make to sustainable development.

More generally, what emerges from this analysis is that there appears to be a remarkable overlap in the type of contributions governments and intergovernmental agencies expect international investors to make to the sustainable development of host countries on the one hand, and private sector stakeholders, especially MNEs and business organizations, envisage themselves as making to the sustainable development of their host countries on the other hand. ${ }^{74}$ These contributions typically go beyond 'do no harm' and actually call for deliberate efforts on the part of foreign affiliates to make an active

74 It is possible that the result, as far as MNEs are concerned, is influenced by the selection of the firms involved, namely firms that are among the largest MNEs world-wide (measured by their foreign assets) and that, by virtue of being members of the World Business Council for Sustainable Development and/or the United Nations Global Compact, are leading-edge companies as regards attention being paid to sustainability issues. 
FIGURE 3 Matrix of sustainability characteristics of FDI: three intergovernmental instruments, by (a) economic, (b) environmental, (c) social and (d) governance dimension and characteristic

a. Economic Dimension of Sustainable FDI

\begin{tabular}{|c|c|c|c|c|}
\hline & 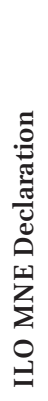 & 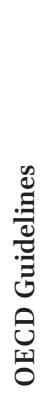 & 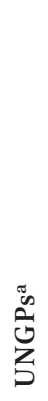 & 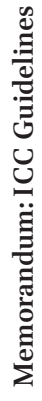 \\
\hline General reference only & & & & \\
\hline Employment & & & & \\
\hline Local linkages & & & & \\
\hline Technology transfer & & & & \\
\hline Infrastructure & & & & \\
\hline $\begin{array}{l}\text { Community } \\
\text { development }\end{array}$ & & & & \\
\hline Equitable distrib. of wealth & & & & \\
\hline Tax accountability & & & & \\
\hline Promote R\&D & & & & \\
\hline $\begin{array}{l}\text { General and specific } \\
\text { indicator }\end{array}$ & & & & \\
\hline $\begin{array}{l}\text { General or specific } \\
\text { indicator }\end{array}$ & & & & \\
\hline
\end{tabular}

b. Environmental Dimension of Sustainable FDI

\begin{tabular}{|c|c|c|c|c|}
\hline & 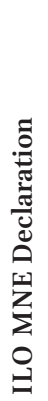 & 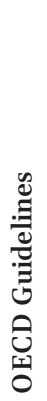 & $\begin{array}{l} \\
\\
\tilde{n} \\
\text { ஸे } \\
\vdots \\
5\end{array}$ & 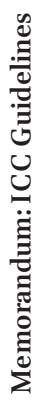 \\
\hline General reference only & & & & \\
\hline Resource management & & & & \\
\hline Pollution controls & & & & \\
\hline Low carbon footprint & & & & \\
\hline Waste reduction & & & & \\
\hline Biodiversity protection & & & & \\
\hline Climate change & & & & \\
\hline Water & & & & \\
\hline Renewable energy & & & & \\
\hline $\begin{array}{l}\text { General and specific } \\
\text { indicator }\end{array}$ & & & & \\
\hline $\begin{array}{l}\text { General or specific } \\
\text { indicator }\end{array}$ & & & & \\
\hline
\end{tabular}




\begin{tabular}{|c|c|c|c|c|}
\hline \multicolumn{5}{|c|}{ c. Social Dimension of Sustainable FDI } \\
\hline & 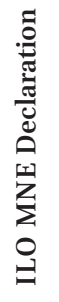 & 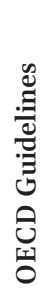 & $\begin{array}{l}\text { n } \\
\text { 崩 } \\
Z\end{array}$ & 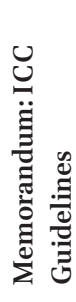 \\
\hline \multicolumn{5}{|l|}{ General reference only } \\
\hline \multicolumn{5}{|l|}{ Labour rights } \\
\hline \multicolumn{5}{|l|}{ Skills enhancement } \\
\hline \multicolumn{5}{|l|}{ Public health } \\
\hline \multicolumn{5}{|l|}{ Workplace safety } \\
\hline \multicolumn{5}{|l|}{ Non-discrimination } \\
\hline \multicolumn{5}{|l|}{ Fair wages } \\
\hline \multicolumn{5}{|l|}{ Benefits } \\
\hline \multicolumn{5}{|l|}{ Human rights } \\
\hline \multicolumn{5}{|l|}{ Indigenous rights } \\
\hline \multicolumn{5}{|l|}{ Gender } \\
\hline \multicolumn{5}{|l|}{ Resettlement } \\
\hline \multicolumn{5}{|l|}{ Cultural heritage protection } \\
\hline \multicolumn{5}{|l|}{$\begin{array}{l}\text { General and specific } \\
\text { indicator }\end{array}$} \\
\hline General or specific indicator & & & & \\
\hline
\end{tabular}

\begin{tabular}{|c|c|c|c|c|}
\hline & 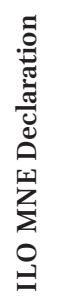 & 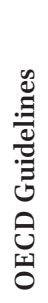 & $\begin{array}{l}\text { n } \\
\text { on } \\
z \\
z\end{array}$ & 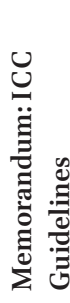 \\
\hline General reference only & & & & \\
\hline Transparency & & & & \\
\hline Local management & & & & \\
\hline Supply chain standards & & & & \\
\hline Consumer protection & & & & \\
\hline Stakeholder engagement & & & & \\
\hline Anti-corruption & & & & \\
\hline Legal compliance & & & & \\
\hline Risk-management systems & & & & \\
\hline $\begin{array}{l}\text { Environ. management } \\
\text { systems }\end{array}$ & & & & \\
\hline Environ./social assessment & & & & \\
\hline Human rights diligence & & & & \\
\hline Corporate governance & & & & \\
\hline $\begin{array}{l}\text { General and specific } \\
\text { indicator }\end{array}$ & & & & \\
\hline General or specific indicator & & & & \\
\hline
\end{tabular}

SOURCE: Independent research conducted for this article; table designed by the authors.

NотE: Bolded characteristics are common characteristics and italicized characteristics are emerging common characteristics, as defined in the text below. 'Key' refers to the percentage of instruments that mention a given characteristic. 'General reference only' refers to a situation in which an instrument contains only a reference to, for example, the promotion of economic development - a general reference. 'General and specific indicators' refers to a situation in which an instrument contains a reference to, for example, the promotion of economic development and, in addition, specifies, for example, the creation of local linkages. 'General or specific indicator' refers to a situation in which an instrument contains either a general reference or a specific reference; this indicator is therefore the most comprehensive one.

a United Nations Guiding Principles on Business and Human Rights 
contribution to sustainable development. Moreover, these expected contributions have become more specific over time. ${ }^{75}$

This suggests that, de facto, an international consensus seems to exist across a range of stakeholder groups as to what sustainable FDI is, reflected in the (indicative) common and emerging common FDI sustainability characteristics.

In addition, given the evolutionary trajectory of these characteristics, a number of the 'emerging common FDI sustainability characteristics' might well 'graduate', to become 'common FDI sustainability characteristics' themselves in a few years. This could occur when new instruments are being formulated, including because new instruments most likely build on existing instruments, complement them or refer to them. ${ }^{76}$ Also, in light of the developments in the recent past and the saliency of the SDGs, it is quite possible that, in the future, additional characteristics will be added, and existing characteristics will become (even) more specific. It is also possible that there will be a broader movement regarding what might be called the intensity of some characteristics, from voluntary to mandatory, as is already occurring in some sectors and in relation to the national implementation of business and human rights standards.

In fact, the 'common' and 'emerging common' sustainability characteristics reflect what is already contained in various instruments (i.e. what is current practice) - they are the result of a stock-taking. The question needs to be raised whether, in light of the SDGs, one should think about what there should be contained in such instruments, in a forward-looking manner, to help advance sustainable development. This may become particularly relevant as countries pursue their national SDG priorities and, in their light, add specific characteristics that are particularly important for them, such as hiring and skilling young people; contributing to vocational skill training; establishing $\mathrm{CO}_{2}$ neutral foreign affiliates; negotiating (in the case of large-scale investment projects) fair

75 Not every characteristic may be relevant for every stakeholder group, or some may be more relevant for some than for others, but some may be relevant for all (eg the observance of human rights). This reality is part of the observation that one size does not fit all, but rather depends on a number of factors mentioned in the text.

76 See, for example, the reference to the ILO Declaration in the Investment Promotion and Protection Agreement Between the Government of the Kingdom of Morocco and the Government of the Federal Republic of Nigeria, 2016. Reciprocal Investment Promotion and Protection Agreement Between the Government of the Kingdom of Morocco and the Government of the Federal Republic of Nigeria (signed on 3 December 2016) art 15, para 1 $<$ https://pca-cpa.org/wp-content/uploads/sites/6/2016/o1/Morrocco-Nigeria-BIT-2016 .pdf $>$ accessed 18 October 2019. 
contracts; ${ }^{77}$ paying a living wage; requiring fair tax payments; or formalizing workers in enterprises linked through business relationships.

In short, the consensus that seems to be emerging is strong, as it includes a wide range of stakeholders and is underpinned by intergovernmental instruments that are based on a broad consensus of governments.

This convergence, in turn, could have a strong signaling effect for all stakeholders seeking to promote sustainable FDI for sustainable development. By providing broad-based precedents and a common language across stakeholder groups, the most widely accepted sustainability characteristics, in particular, give not only guidance as to what is acceptable, but they also confer a certain amount of legitimacy on those stakeholders that propose, use or promote them, especially if they are contained in widely accepted international instruments endorsed by governments. It also constitutes a basis on which the interaction between international investors and host countries can build, for example, in the case of countries with weak legislation and in the negotiation of contracts.

Increased FDI flows to developing countries can make an important contribution to reaching the SDGs. However, the issue is not only more FDI but more sustainable FDI, that is, investment that has certain sustainability characteristics. The analysis in this article shows that there appears to be a broad set of increasingly accepted characteristics of what constitutes sustainable FDI, with all stakeholder groups showing a growing propensity to recognize them.

An indicative list of FDI sustainability characteristics constitutes a check-list that can help interested parties - and especially the principal stakeholders in the FDI space - to determine what sustainable FDI is. In fact, the very process of seeking to identify such characteristics can make an important contribution to the international investment debate, including by highlighting particular desirable FDI. More generally, a broadly accepted indicative list of FDI sustainability characteristics, constructed around the common and emerging common FDI sustainability characteristics, gives direction to

77 While there are some institutions that help developing countries negotiate such contracts - especially the African Legal Support Facility (https://afdb.org/en/topics-and -sectors/initiatives-partnerships/african-legal-support-facility/), the CONNEX Support Unit (http://connex-unit.org) and the International Senior Lawyers Project (http://islp .org) - the need for negotiation support has not yet been widely recognized. 
policy and legal development regarding the relationship between host countries and international investors. More specifically, an indicative list based on a broad consensus among principal stakeholders can give guidance to various actors who seek to increase the contribution of FDI to development, including especially governments and international investors; to the WTO's Structured Discussion concerning investment facilitation; and to arbitrators who seek to take the development dimension into account when deliberating investorstate disputes.

At a time when the SDG s have become the lodestar for development policymaking, it is important for national and international efforts in the investment area to contribute fully to the achievement of these Goals. Helping to achieve the SDGs through the promotion of sustainable FDI is a shared responsibility of the international community, host and home countries and MNEs and, indeed, it is in their common interest. MNEs, in particular, need to be aware about what is expected from them, especially when they undertake large-scale foreign investment projects with significant impacts on host countries - in fact, ignoring this may jeopardize their license to operate. An indicative list of FDI sustainability characteristics that are SDG-supportive provides guidance for such efforts. Finding ways and means to promote the acceptance and use of the sustainability characteristics is therefore an important challenge that will need to be addressed by the principal stakeholders in the future. ${ }^{78}$

78 One opportunity where this could be done is during the Structured Discussions taking place in the WTO, considering to develop 'a multilateral framework on investment facilitation'. See, WTO, 'Joint Ministerial Statement on Investment Facilitation for Development' (13 December 2017) WT/MIN(17)/59 <https://worldtradescanner.com/Investment\%20 Facilitation\%2ofor\%2oDevelopment.pdf> accessed 13 April 2018; Felipe Hees and Pedro Mendonça Cavalcante, 'Focusing on Investment Facilitation - Is It That Difficult?' 202 Columbia FDI Perspectives (19 June 2017) <http://ccsi.columbia.edu/files/2016/10/ No-202-Hees-and-Cavalcante-FINAL.pdf> accessed 18 October 2019; Axel Berger, 'What's Next for the Investment Facilitation Agenda?' 224 Columbia FDI Perspectives (23 April 2018) <http://ccsi.columbia.edu/files/2016/10/No-224-Berger-FINAL.pdf> accessed 18 October 2019 . 